\title{
MAXIMIZING YOUR ORGANIZATION'S COLLABORATIVE CAPACITY THROUGH GOAL-BASED TRANSIENT COLLABORATIONS
}

\author{
*Hamid NOORI \\ *Adrian TAN \\ Wilfrid Laurier University, Canada
}

\begin{abstract}
How may companies ensure that their collaborations outcomes could be consistently competitive, equitable and flexible? This article proposes that by adopting the transient collaboration perspective, companies and their partners can design their collaborative networks to be more efficient and effective in terms of collaboration performance. The article describes the necessary conditions for a group of companies to establish such networks, offers a roadmap to guide the construction of such networks together with an industry example, and provides a set of principles for a focal company to maximize its collaboration success while operating in such a network.
\end{abstract}

Keywords: Networks, Strategic Alliances, Supply Chain, Transient Collaboration

\section{INTRODUCTION}

A recent article in Scientific American discusses how various means of cooperation can be found among diverse species in nature, ranging from the level of genes and simple cells to animal herds and human societies. Cooperativeness is so widespread because it confers positive benefits for both individuals and their groups through self-perpetuating and self-reinforcing behavior (Nowak, 2012). When we reflect upon the business world, it becomes just as clear that no company operating as an isolated entity can hope to thrive for long in today's volatile and globalized business environment. Many business pundits and management journals have consistently spread the message about the importance of collaboration to boost companies' competitiveness. In response, many leading businesses have turned to strategic alliances in an effort to create sustainable competitive advantages for their organizations (Baraldi, 2008). Interorganizational collaboration, defined in this article as the voluntary cooperation of two or more independent business entities where each respectively contributes resources in common and work together to meet jointly agreed objectives, is therefore widely recognized as the linchpin strategic activity that can ensure the continued survival, viability and prosperity for business enterprises (Powell, 1998).

Though companies understand the importance of collaboration, and some are actively engage in various cooperative strategic alliances with partners, many of these companies are less likely to realize that standardizing the norms of their collaborations will be just as important to sustain successes. These norms refer to the rules that govern how companies interact with one another throughout their association. The norms determine the behaviors, common practices and mutual understandings that underlie all joint efforts between two or more cooperating companies. However, for many companies the norms that developed for a specific collaboration will tend to be customized to the particular business requirements, precedents or relative power of the partners involved. This is especially true for small or medium-sized enterprises that may not follow consistent corporate collaboration strategies. As such, the cooperative norms for these companies will be customized on an ad-hoc and individual basis with each partner. Entering into customized cooperation arrangements may appear to be the right thing to do, as it will seemingly increases cooperative opportunities 
for a given company. However, a customized approach can actually serve to negate one of the most important aspects of collaboration i.e. the networking effect that a company can leverage from all its past collaborations. This is because such a company will find it difficult, if not impossible, to get its respective partners to network with one another primarily because of the need to separately re-negotiate the norms or expectations in new collaborations. Networking across collaborations is critical because it can create fresh synergies from the novel recombination of different partners' resources, and also act to link and draw in valuable new partners for a focal company through continued network expansion (Dekkers, 2009; Gulati et al., 2012). A focal company benefits directly from such networking because it can now access the novel resources of new partners, and will benefit indirectly from the increased prosperity of its existing partners. In other words, a company that standardizes its collaboration norms will be better placed to move beyond isolated one-to-one dyadic alliance arrangements, and create a wider interconnected interaction space or ecology of collaborating relationships (Noori and Lee, 2006; Williamson and De Meyer, 2012). If a company decides to standardize its collaboration norms, which set of norms should it adopt? Logically, such norms should be those that can serve to expand and maximize a company's collaboration capacity. Such maximization can be achieved only if companies can construct a collaboration ecology of partners that operates according to rules and principles that supports increased collaboration opportunities and flexibility, and access to new partners. We believe that the key toward constructing an ecological network that approximates this ideal state is for companies to adopt the perspective that regards all interorganizational collaborations as a purely transient process. In this perspective, that we refer to as the transient process of collaborations, interorganizational collaborations is viewed as a process by which a group of companies commits to collaborate with one another under the mutual understanding that all their interactions will be transient, have goal-based durations and be based around agreed objectives. Once these joint objectives are met, these companies may freely exit their associations, and perhaps join into new joint efforts with other partners in the wider network. Over time, some companies may interact repeatedly, but each time the alliance decision is always to pick only the most appropriate partners within the collaboration ecology for each given objective (Noori and Lee, 2009).

It is possible to have such collaboration ecologies existing within a company. Consider the case of Valve Corporation, a game software development company based in Bellevue, Washington. The internal organization of this company is deliberately flat without a formal hierarchical management structure to encourage self-organized collaborations among employees. Employees in Valve decide for themselves which collaboration groups they will choose to join to contribute their efforts (Suddath, 2012). Employees may choose to join or leave different groups, or contribute their efforts to multiple groups. At the end of the day, each employee's compensation is based on a peer review of their individual contributions or value rankings to the company (Valve, 2012). Valve hiring policies are largely instrumental in enabling such flexible collaborative behavior. The company only hires highly self-motivated employees with both specialist and general skills who will actively seek to work on innovative and creative tasks. Valve's style of enabling very flexible and creative collaborations among employees has been extraordinarily successful at making them a market leader among video games developers (Abrash, 2012; Varoufakis, 2012).

Consider also how movie industry works. Movie-making is an extraordinarily complex and creative process that requires the collaborative efforts of multiple specialist parties (Shamsie et al., 2009). These specialist parties typically consist of independent agents such as talent scouts, script-writers, directors, producers, actors, special effects companies, distributors and others. Specialists may change from movie to movie to reflect the respective unique requirements of each movie. After a movie is completed, its set of specialist parties will disband and the various parties may then sign up to work on other movie projects. These constant collaborative changes in movie-making efforts allow these various parties to share best practices, inspire ideas and spur imaginative creativity in the industry. The remarkable flexibility and capability of the parties in the movie industry to create transient networks to collaborate on specific productions ultimately lead to more efficient and effective movie-making for the industry as a whole. As a successful arbiter of public 
opinion, preferences, beliefs and even values (Wiesenfeld and Cattani, 2010), the movie industry rakes in approximately US $\$ 35$ billion in annual revenue for cinema and DVD sales or rentals for the domestic US market alone (Hennig-Thurau et al., 2007). The question we ask is how may a company construct and make use of a transient collaboration network to improve its performance effectiveness? To aid this aim, we will describe the necessary conditions to enable the transient process, explain how companies may construct a transient ecology, provide an example of such a construction in industry, and describe how a focal company can maximize its business opportunities in such ecologies.

\section{NECESSARY CONDITIONS}

Notwithstanding the advantages of interorganizational collaboration, it is neither a given nor a must for any company to collaborate with others. Instead, it is a strategic activity that each company's management has to make a careful decision to adopt or to forgo on the basis of whether collaborations will support or undermine their organizational objectives (Ring et al., 2005). Just as collaboration is not necessarily for every company, similarly, the transient process in collaboration is also not universally applicable to all companies. Prior research has shown that transient collaboration networks can be more effective at coping with uncertain and volatile environments (Noori, 2009). Companies that operate in transient collaboration networks are more flexible and are faster at adjusting their products or services to match ever-changing customer requirements. These companies will thereby have a performance advantage over other companies outside such networks. A set of necessary conditions, or enablers, is required to establish the transient process of collaboration among a group of companies. The necessary conditions are the relative independence, niche operator characteristics, common communication technology, win-win propositions and strategic group mindset of a given group of companies. Companies considering the transient process should first evaluate themselves and their partners early in the assessment phase to see if they can qualify in terms of these necessary conditions. Details of these necessary conditions are described as follows:

Independence - This is defined as the ability for individual companies in a collaborating network to make operational decisions in their own interests without having to consider the issue of ownership links among them. This denotes the absence of hierarchical fiat, and thereby any corresponding ownership influence, to govern the interactions among these companies (Powell, 1990). Independence means that each company possesses the free scope to makes all its business decisions on purely economic grounds, so that it can maximize profits and seek only to benefit its own shareholders. The independence condition is important because it means that companies will not be forced to collaborate with less optimal sister-companies just to satisfy corporate requirements to maximize the utilization of all corporate-owned resources. Rather, the independence condition will help ensure that all collaboration decisions will be made based only on the necessary efficiency and effectiveness to achieve joint collaborative objectives.

Niche operator characteristics - A major reason why companies collaborate is to obtain access to resources that are not available to them. Therefore, companies that possess identical resources will have little motivation to collaborate with one another, as they will not obtain access to any novel resources through their collaborations. Ideally, all potential collaboration partners within a network should possess resources that are unique or sufficiently dissimilar to each other to be useful (Uzzi and Dunlap, 2005). In other words, each company in a collaboration network should be niche operators with respect to their type of resources. This is necessary because overlapping or identical resources located in a collaboration ecology will be effectively redundant or be underutilized (Li, 2008).

Common communication technology - Another reason for companies to seek to work cooperatively with one another is that collaboration allows companies to more quickly adjust their resources mix to changing environmental conditions. However, such flexibility can only be assured if companies will incur low setup costs whenever they exit collaborations or enter new ones. In this aspect, common platforms in communication and coordination technology across companies become an important necessary condition to 
enable the successful integration of collaborative efforts to their joint production (Jap and Mohr, 2002). Standard communication technology reduces the barriers to switching partners or incorporating new partners into a collaboration ecology (Lawrence et al., 2005). Companies nowadays have minimum issues to establish this condition for themselves and their potential partners because of the increasingly widespread availability of cheap, standardized and effective communicative technology in today's world (Noori and Lee, 2009).

Win-win proposition - Because collaboration is a choice, companies will collaborate only if they can do better by doing so. To be sustainable over the long term, a collaboration ecology has to provide an overall win-win proposition for all of its participants (Whipple and Frankel, 2000). A member company that could not derive a positive net performance benefit over time from its participation in such a network will eventually exit from there. A member company will also exit a collaboration ecology if its participation there results in lower returns than non-participation. This condition requires companies to balance value flows in their collaboration ecology to ensure that all desirable participants can obtain fair and mutually acceptable returns from their collaborative efforts or investments. Win-win propositions can be more likely where collaborating companies have different internal objectives from entering into a collaboration effort, although all companies can still have a joint collaborative objective in common. For instance, moneymaking may not be the only objective for all companies in collaboration. Some other possible internal objectives may include the intent of companies to make use of collaborations to enter new markets ( $\mathrm{Yu}$ et al., 2011), to learn from partners (Inkpen, 1996), to buffer against environmental shocks (Miner et al., 1990), to achieve innovation outcomes (Miles et al., 2009), to satisfy customer requirements, to build reputation, or to address market complaints (Beamon, 1999). Irrespective of their internal objectives, companies will still have as their common motivation the desire to make the collaboration successful. Holding different internal objectives will help ensure a non-zero sum game outcome to a collaboration, where a gain to one company does not come at a loss to another company, and thereby lead to win-win propositions. For example, a company that primarily seek to learn from its collaborative partners can willingly forgo its share of the financial profits, and therefore allow a partner whose primary motive for collaboration is money to garner more profits for itself. Companies can even be willing to give up individual short-term gains to obtain long-term gains for all in the group (Donaldson and Schoemaker, 2013).

Strategic group mindset - A strategic group mindset means that all the member companies in a collaboration ecology see themselves as constituting a well-defined strategic group that chooses to work with one another. Such a mindset includes clear expectations on how the companies will conduct collaborations with one another. A strategic group mindset is a necessity to reduce coordination costs, ensure fair division of collaboration rewards, ensure that conflicts can be avoided, or else be amicably resolved (Peteraf and Shanley, 1997).

\section{CONSTRUCTING A TRANSIENT COLLABORATION ECOLOGY}

If a group of companies do not already possess the above conditions, it does not mean that they are by default permanently excluded from implementing the transient process of collaboration. Rather, such companies may acquire or built such conditions over time, as a part of the construction of their transient collaboration ecology. How may a collaboration ecology be constructed from scratch? Though it might seem daunting to begin anything from square one, the good news is that many companies already possess the basic means to initiate the process of constructing a collaboration ecology. For instance, most companies will have at some time carried out some forms of collaborative efforts with other companies. These may be just simple associations with other companies to discuss common interests, or straightforward cooperation on some jobs, or even more complex joint efforts and collaborative investments in major projects. As with everything new, an initial group of companies will need to take the lead to begin the process to build a transient ecology for them. These companies can make use their prior relationships with existing partners as the initial building blocks for a new ecology. A question to ponder will be if it might be just easier for every company to join an 
existing transient network. That is always a possible option, if such a network already exists. However, such networks may not be yet available for every industry or location, or an existing network may not fully match a company's requirements. In addition, companies that take the initiative to build their own collaboration ecology may find it more beneficial for them. For instance, by being founders, these companies can gain special advantages by being linked to every new member in the group (Flanagin et al., 2001).

A major challenge to these companies' efforts to build a new collaboration ecology could be internal resistance from within their workforces. Such resistance may arise from unease at cooperation with potential competitors, or just from a general reluctance to depart from existing work practices (Strebel, 1996). It is vital for these companies to invest time and effort at this initial stage to convince their various workforces of the necessity and advantages of collaboration (Uzzi and Dunlap, 2005). Buy-in from all involved parties, ranging from the top and middle management teams, to the employees responsible for daily operations is necessary to ensure success. For a company that wanted to build such a network, and is able to interest a group of other companies in the idea, we have designed the following roadmap to guide such an effort. The roadmap is illustrated in Figure 1, and consists of the four phases of Assessment, Initiation, Growth and Renewal.

Assessment Phase - The Assessment phase is a flexible and unstructured stage when the core group of founder members performs a voluntary self-assessment of their group attributes to find out if they can collectively meet the five necessary conditions required to create a transient ecology. From the practical point of view, it is more appropriate to interpret these conditions as general principles rather than absolute requisites. For instance, as stated earlier, the independence of companies in such a network is critical to help prevent hierarchal interference from common owners on collaboration efforts (Powell, 1990). In practice, this does not mean that companies cannot hold minor ownership stakes in each other, as long as the principle of non-interference is recognized and upheld. However, as explained in the earlier section, the recommended practice to ensure complete independence is that companies do not have overlapping ownership interests in each other. In the same way, the companies will need to decide if there is sufficient dissimilarity across their resources for useful complementarity (Uzzi and Dunlap, 2005). Very similar companies may not make good partners except perhaps for special situations that require only economy of scale to be realized. At this stage, the core group of companies may find it expedient to review the eligibility of various members and to change them out as necessary.

With regard to common communicative technology, aside from agreeing on common standards, these companies will also need to decide on the level of technical integration needed for collaboration operations in their industry (Kuhnle, 2009). This is also a good time to establish and open multiple lines of communication across different levels among the collaborating companies. These can include personal links among their employees or functional links across their departments that interact with one another. Multiple lines of communications not only permit more collaboration opportunities to be exposed, but also provide more forums for learning or conflict resolutions. The condition of providing for win-win propositions is more a reflection of the fundamental managerial philosophies of the core companies. As such, it can be difficult to quantify or to assess if any particular company understands the rationale for win-win propositions, and will operate accordingly in future collaborations. It is more likely that individual companies may only be able to assess the strength and depth of their fellow-companies' commitment to collective benefits by observing if they are consistently operating in good faith throughout all phases of jointly constructing the ecology. Companies that do not meet this condition of win-win propositions can be identified as those that will consistently seek to promote their self-interests even if by doing so it will disadvantage their partners (Parkhe, 1993). Again, the Assessment stage is the time for all the companies to decide on the right mix of members in the network.

A strategic group mindset comes about when a group of companies come to view themselves as a credible and legitimate network that is their preferred venue for any collaboration effort (Human and Provan, 2000). 
The initial development of such a mindset among employees depends on how much effort the top management teams in each company will invest in the construction of the ecology. The greater the emphasis the top management teams place on the importance of the new ecology, the stronger the initial development of the mindset within the companies. The mindset can then be further cemented from repeated and positive interactions among these companies through additional collaborations. If a core group of companies can successfully complete the Assessment phase, they can be in a more realistic position to move to the next phase of Initiation in constructing their collaboration ecology.

Initiation Phase - During the Initiation phase, the companies will need to agree on specific rules that will govern their future interactions. One way to conceptualize this phase is to liken it how a new club may organize its constitution and expected rules of behavior for members. For instance, these companies need to agree on how individual member companies may approach each other to seek or to propose collaborative projects. Standard templates of terms on mutual confidentiality, liabilities, coordination, value flows or payment arrangements should be developed and communicated. These companies should also agree on conflict resolution methods to be used in cases of disputes or disagreements. For instance, they could agree beforehand to attempt to use mediation as a means of resolution before any party will turn to legal recourse. The Initiation phase is also the time for companies to establish regular meeting schedules for their representatives. These should include formal venues for serious business discussions, as well as informal venues such as luncheons or golf tournaments to permit spontaneous discussions among member companies (Walls, 2012). For instance, the companies can agree to meet formally once a quarter to review and revise the rules of their collaboration ecology, and to meet informally once a month for a luncheon meeting to discuss business trends or opportunities. Special features such as the invitation of business leaders as keynote speakers to such meetings can add additional value and relevance to all members. The companies can consider levying a minor fee to fund meeting arrangements and other coordination expenses (Human and Provan, 2000).

The core companies will also need to establish rules or guidelines for admitting new members into their ecology. For instance, the eligibility of new members may be assessed based on the relative rarity of their resources as compared with those of current members, the extent to which they meet the necessary conditions for operating in the transient ecology, or on their reputations within the industry for acting in good faith in collaborations. By the same token, these rules may also be used to assess the eligibility of current members. For instance, companies that do not collaborate in good faith may have their membership revoked by a majority vote. On a related issue, the core companies will need to decide on the sanctions to be imposed on any member that broke the rules of their association. These may range from imposing fines, or requirements to withdraw from disputed projects, up to expulsion from the ecology. Aside from the above activities, the Initiation phase is also a time for all existing members to begin to know and understand each other, and to start forming lasting links with one another. This will set the stage for the next phase of Growth, which is to expand their ecology beyond the initial core group.

Growth Phase - Intercompany coordination is required for all collaboration efforts in a network. Such coordination is undertaken by certain member companies we refer to as hubs. Hubs act to locate market demands, and to coordinate member companies within the ecology that possess the right resources to fulfil such demands (Belderbos et al., 2012). Initially, any member company in a new collaboration ecology may act as a hub, but eventually, some companies may choose to specialize as full-time hubs that only coordinate others. Prior research has shown that hubs play a critical role in expanding the size, scope and marketability of collaboration ecologies (Magretta and Fung, 1998). Hubs essentially act as the boundary spanners on behalf of their ecologies because they need to both accurately track external demand patterns, as well as be able to quickly identify, recruit and coordinate the most appropriate network resources to satisfy such demands (Belderbos et al., 2012). While doing so, they still have to balance the potentially conflicting interests of all involved parties, either customers or member companies, against the overall interests of the ecology (Friedman and Podolny, 2006). Though it may be a difficult role, being a hub can be advantageous 
to a company. A hub has a more central position compared with non-hub companies, and this has better access to information links that can reveal major economic trends, and future opportunities or threats in the environment (Gulati, 1999). The attractions of being a hub can lead to a proliferation of companies seeking to become hub companies. In this aspect, a proliferation of hubs in a new collaboration ecology can be beneficial during the Growth phase. The benefits arise from the competition among hubs to become the preferred coordinator among many competing hubs. To be chosen as a preferred coordinator, a hub has to build a superior reputation among both customers and member companies for its efficiency, effectiveness and trustworthiness in coordination. For instance, a hub may work with member companies to further develop and extend their capabilities to make them more attractive to customers. A hub may also seek out and recruit new members with valuable resources into the ecology for the same purpose. In the same way, a hub may actively promote its ecology's product offering to additional customers (Koka et al., 2006). All these activities will increase potential opportunities for the hub to act as the prime coordinator in its network. It will also directly serve to grow the reputations, capabilities, resources of members, and customer demand for the ecology.

The Growth phase of a collaboration ecology is critical because increased size, capabilities and marketability create proportionally more business opportunities for every company in the network. All else being equal, a larger ecology will greatly expand the competitive advantages of its members. We believe that hub companies should be allowed to act as the main engines of growth and to take the lead in growing the ecology. This will result in emergent, rather than directed growth, which will ultimately result in a collaboration ecology that is more attuned to business realities, members' abilities, and market requirements.

Renewal Phase - Once it is up and running, a transient ecology will need constant renewal to stay relevant and successful. Such renewal takes place at two different levels in the ecology. The first is at the level of an individual company, and is best served by viewing the member companies as learning organizations that continually draw tacit lessons from their collaborations on how they may improve their cooperation processes and joint business offerings (Powell, 1998). The transient process of collaboration allows member companies to freely end and begin new ties of collaborations with any other member or hub company. This allows the formation of emergent groupings that can be easily adaptable to handle any fast-changing demand requirements. As these companies continually re-connect to collaborate, they will learn from one another about processes or routines that work well, and on those that will not work (Irick, 2007). This renewal process will act over time to improve the fitness of individual companies to match the particular exigencies of the network. The second type of renewal takes place at the level of the ecology itself. In this respect, the hubs will also play a critical role. As part of their coordinative functions, from time to time, hubs will seek to recruit new companies from the outside, including drawing companies from other ecologies. In addition, hubs will also be among the first companies to be aware if an existing member company decide to cease collaborating in their ecology, and leave to join another one. This means that hubs will tend to be more cognizant of changes or trends taking place in other ecologies. With their better knowledge of collaborative practices in other ecologies, hubs are the natural change-agents to work toward the continued renewal and improvement of their ecology. It should also be noted that ecologies might not be closed or exclusive networks (Doganoglu and Wright, 2010). A given company can be a member in two or more different ecologies. Such companies can still collaborate with partners in different ecologies as long as they adhere to the respective rules of these ecologies. Companies can select between working with partners from different networks depending on their customers' particular requirements. Companies operating in more than one such ecology can learn and apply operational lessons across them. As may be seen in Figure 1, the construction process does not come to a halt after the Renewal phase. Rather, the process is continually iterated across the Initiation, Growth and Renewal phases for as long as the ecology exists. 


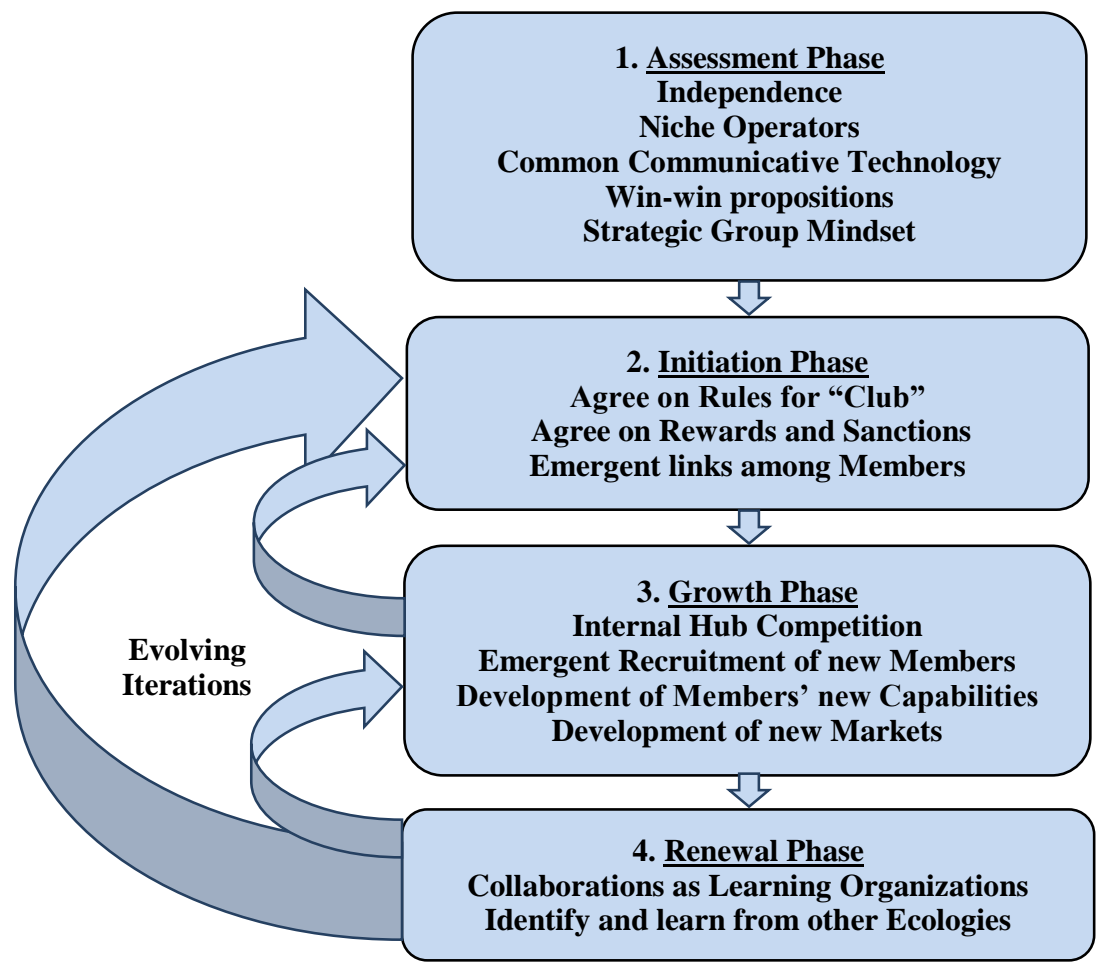

Fig 1. Roadmap to the Construction Dynamics of a Transient Collaboration Ecology

\section{PRINCIPLES FOR A FOCAL COMPANY}

How may a particular company achieve sustained collaborative success with a transient collaboration ecology as described above? We can offer a roadmap of principles to guide the network behavior of a focal company. The four principles for such a company to keep in mind are its Reputation, Best-in-Class Resources, Superconnector Links and Hub-centricity. These principles are illustrated in Figure 2, and further described below:

Reputation - A company that seeks success through collaboration with others must always maintain a good reputation among its peers. A company's reputation is maintained or enhanced by its reliability in performance, and the absence of its willingness to take advantage of its partners' vulnerabilities (Williamson, 1993). Reputation is important because a collaborative network with multiple ties among members creates what that is referred to as a small-world network. In such networks, every company can be connected with every other company via only a few intermediaries (Kogut and Walker, 2001). In other words, bad news can travel quickly in such a network. A company that cheats another will quickly find that other companies will know about the incident soon, and become chary of further collaborations with it. A bad reputation can adversely affect even a company that controls a unique and valuable resource. Such a company may still always find partners because of the demand for its resource. However, the company may not attract the best partners, nor may it always receive the best terms for its collaborative efforts. Reputation comes again into play because companies in network collaborations will tend to introduce and recommend good partners to each other for new projects (Powell, 1990). A company with an excellent reputation can find many unexpected windows of opportunity to open up through the medium of recommendations from appreciative partners (Xin and Pearce, 1996). Conversely, a company with a poor reputation will lose opportunities due to a lack of good recommendations, or even to adverse comments from others.

Best-in-Class Resources - A focal company operating in a collaboration ecology is not exempted from competitive pressure because such a company will compete based on the quality of the resources it can offer 
to the hubs. The focal company's competitors will be companies that hold similar resources immediately outside its ecology. For instance, if an external company holds a similar resource with a superior quality, and is available for collaboration, it can be invited by the hub companies to join the ecology. The entrance of such a competitor may soon spell the eventual exit of the focal company. In short, to ensure its continued tenure in the ecology, a focal company has to ensure that it has a best-in-class level of quality for the particular resources held by it as compared against all potential external competitors with similar resources. On a similar note, even if no external companies with similar resources are currently available to join them, if a focal company failed to maintain a sufficiently high level of quality for its resources that might motivate its fellow member companies to begin the development of similar resources of superior quality. If nothing else, as a matter of survival, the hub companies will have the self-interest to redevelop these resources elsewhere in order to meet customers' requirements. In short, a focal company needs to maintain a competitive level of quality so that its resources for collaboration are best in class against all potential competitors, or else runs the risk of being supplanted in one way or another.

Superconnector Links - While every company in a collaboration ecology has the potential to be linked to one another, individual companies may maintain deeper relationship ties with some companies than others. This may be because of historical reasons such as prior collaborations, or operational reasons to run a long-lasting project, or simply a matter of close personal ties between the managers. The maintenance of close ties can be expensive in terms of a company's efforts and time, and is therefore not likely to be feasible to be extendible to all companies in a large network. A focal company could only afford to maintain close ties with a small number of fellow companies and it needs to be strategically selective in its choice of companies. An important criterion in its choice will be the identification of companies that are superconnectors within the network. A superconnector is a company that has an extensive number of links to other companies in the network (Prashantham and Birkinshaw, 2008). Superconnectors may come into being because of their long history of collaboration with others, ownership of valuable resources, operation as a hub, superior networking skills, and others. The value of a superconnector lies mainly in the additional connective access it can provide for the focal company to reach other companies. A focal company will find that maintaining close ties to superconnectors can be a more efficient and effective way to locate and connect with relevant partners for future projects.

Hub-centricity - The advantages of being a hub company, and some of the associated difficulties involved to become one, have been discussed elsewhere. A focal company should always still strive to be a hub where possible because the advantages far outweigh the difficulties (Choi and Linton, 2011). However, there are circumstances where it is not possible for a focal company to become a hub. For instance, a collaboration ecology may develop in such a way that one company became such an efficient hub that no others can be competitive against it. Even under this scenario, a focal company can still aspire to become an assistant hub. An assistant hub can help provide support to the main hub by coordinating second-tier partners where possible within its subset of the network (Magretta and Fung, 1998). In summary, a focal company should always keep an eye out for any chance to act as a hub coordinator wherever possible to maximize its success in a collaboration network.

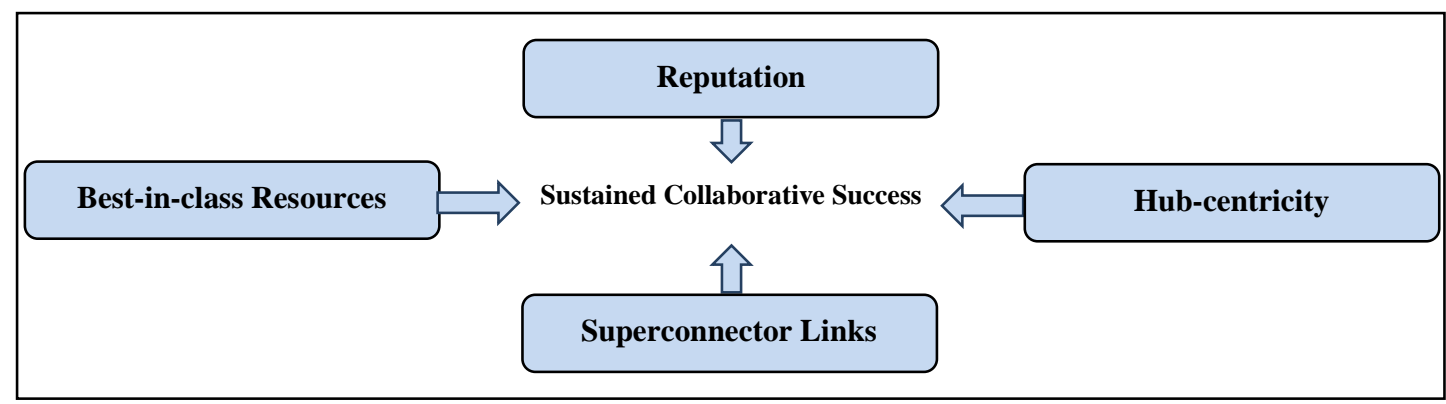

Fig 2. Principles for a Focal Company in a Transient Collaboration Ecology 


\section{CONCLUSIONS}

The term collaboration ecology is used to describe a cooperative network in this article because it invoke the notion of a whole system that depends on the interactions of independent entities, relationships, value flows, and transformations that is inherent in natural ecologies as well as in companies' collaborative spaces. Additionally, the term is useful because it suggests that it is possible for companies to choose and operate in different collaboration ecologies. As an analogy, in the natural world, plants and animals in a desert ecology will interact according to different rules or principles than from those in a forest ecology. Of course, in nature, ecologies typically evolve over long periods through random changes and biological selections. In contrast, a specific type of collaboration ecology can conceivably be designed and brought into existence by companies that recognize that such a possibility exists.

In this article, we describe a novel process that can increase business opportunities for companies called the transient process of collaboration. The contributions of this article are to provide a description of this process, to explain its advantages in a collaboration ecology, to explicate its necessary conditions, to offer a roadmap and example on how to construct a transient collaboration ecology, and to recommend basic principles for a focal company operating in such a collaborative ecology. Ultimately, this article provides a practical guide to companies on how they may create collaboration ecologies with transient collaboration rules that will favor the maximization of their collaborative capabilities. 


\section{REFERENCES}

Abrash, M. (2012), Valve: How I Got Here, What It's Like, and What I'm Doing, Ramblings in Valve Time, available at: http://blogs.valvesoftware.com/abrash/valve-how-i-got-here-what-its-like-and-what-im-doing$2 /$.

Baraldi, E. (2008), Strategy in industrial networks: Experiences from IKEA, California Management Review, Vol. 50, No. 4, pp. 99-126.

Beamon, B.M. (1999), Measuring supply chain performance, International Journal of Operations \& Production Management, Vol. 19, No. 3-4, pp. 275-292.

Belderbos, R., Gilsing, V. and Lokshin, B. (2012), Persistence of, and Interrelation Between, Horizontal and Vertical Technology Alliances, Journal of Management, Vol. 38, No. 6, pp. 1812-1834.

Choi, T. and Linton, T. (2011), Don't Let Your Supply Chain Control Your Business, Harvard Business Review, Vol. 89, No. 12, pp. 112-117.

Dekkers, R. (Ed.). (2009), Dispersed Manufacturing Networks: Challenges for Research and Practice, London, UK, Springer, 1sted.

Doganoglu, T. and Wright, J. (2010), Exclusive dealing with network effects, International Journal of Industrial Organization, Vol. 28, No. 2, pp. 145-154.

Donaldson, T. and Schoemaker, P.J.H. (2013), Self-inflicted industry wounds: early warning signals and Pelican Gambits, California Management Review, Vol. 55, No. 2, pp. 24-45.

Flanagin, A.J., Monge, P. and Fulk, J. (2001), The value of formative investment in organizational federations, Human Communication Research, Vol. 27, No. 1, pp. 69-93.

Friedman, R. and Podolny, J. (2006), Differentiation of Boundary Spanning Roles: Labor Negotiations and Implications for Role Conflict (SSRN Scholarly Paper No. ID 935148), Rochester, NY: Social Science Research Network, available at: http://papers.ssrn.com/abstract=935148.

Gulati, R. (1999), Network location and learning: The influence of network resources and firm capabilities on alliance formation, Strategic Management Journal, Vol. 20, No. 5, pp. 397-420.

Gulati, R., Puranam, P. and Tushman, M. (2012), Meta-organization design: Rethinking design in interorganizational and community contexts, Strategic Management Journal, Vol. 33, No. 6, pp. 571-586.

Hennig-Thurau, T., Henning, V., Sattler, H., Eggers, F. and Houston, M. (2007), The last picture show? Timing and order of movie distribution channels, Journal of Marketing, Vol. 71, No. 4, pp. 63-83.

Human, S.E. and Provan, K.G. (2000), Legitimacy building in the evolution of small firm mutilateral networks: A Comparative study of success and demise, Administrative Science Quarterly, Vol. 45, No. 2, pp. $327-365$.

Inkpen, A.C. (1996), Creating knowledge through collaboration, California Management Review, Vol. 39, No. 1, pp. 123-140.

Irick, M.L. (2007), Managing Tacit Knowledge In Organizations, Journal of Knowledge Management Practice, Vol. 8, No. 3, p. 2nd.

Jap, S.D. and Mohr, J.J. (2002), Leveraging internet technologies in B2B relationships, California Management Review, Vol. 44, No. 4, pp. 24-38.

Kogut, B. and Walker, G. (2001), The small world of Germany and the durability of national networks, American Sociological Review, Vol. 66, No. 3, pp. 317-335. 
Koka, B.R., Madhavan, R. and Prescott, J.E. (2006), The evolution of interfirm networks: Environmental effects on patterns of network change, Academy of Management Review, Vol. 31, No. 3, pp. 721-737.

Kuhnle, H. (2009), Self-similarity and criticality in Dispersed Manufacturing: A contribution to production networks control, in Dekkers, R. (Ed.),Dispersed Manufacturing Networks: Challenges for Research and Practice, London, UK, Springer, first., pp. 59-76.

Lawrence, T.B., Morse, E.A. and Fowler, S.W. (2005), Managing your portfolio of connections, MIT Sloan Management Review, Vol. 46, No. 2, pp. 59-65.

Li, J. (2008), Asymmetric interactions between foreign and domestic banks: Effects on market entry, Strategic Management Journal, Vol. 29, No. 8, pp. 873-893.

Magretta, J. and Fung, V. (1998), Fast, global, and entrepreneurial: Supply chain management, Hong Kong style - An interview with Victor Fung, Harvard Business Review, Vol. 76, No. 5, pp. 102-114.

Miles, R.E., Miles, G., Snow, C.C., Blomqvist, K. and Rocha, H. (2009), The I-form organization, California Management Review, Vol. 51, No. 4, pp. 59-74.

Miner, A.S., Amburgey, T.L. and Stearns, T.M. (1990), Interorganizational Linkages and PopulationDynamics - Buffering and Transformational Shields, Administrative Science Quarterly, Vol. 35, No. 4, pp. 689-713.

Noori, H. (2009), Knowledge Network and Smart Supply Chains - A Presentation, Wilfrid Laurier University, Waterloo, ON.

Noori, H. and Lee, W.B. (2006), Dispersed network manufacturing: adapting SMEs to compete on the global scale, Journal of Manufacturing Technology Management, Vol. 17, No. 8, pp. 1022-1041.

Noori, H. and Lee, W.B. (2009), Dispersed Network Manufacturing: An Emerging Form of Collaboration Networks, in Dekkers, R. (Ed.),Dispersed Manufacturing Networks: Challenges for Research and Practice, London, UK, Springer, 1sted., pp. 39-58.

Nowak, M.A. (2012), Why We Help, Scientific American, Vol. 307, No. 1, pp. 34-39.

Parkhe, A. (1993), Strategic Alliance Structuring - a Game-Theoretic and Transaction Cost Examination of Interfirm Cooperation, Academy of Management Journal, Vol. 36, No. 4, pp. 794-829.

Peteraf, M.A. and Shanley, M. (1997), Getting to Know You: A Theory of Strategic Group Identity, Strategic Management Journal, Vol. 18, pp. 165-186.

Powell, W.W. (1990), Neither Market nor Hierarchy - Network Forms of Organization, Research in Organizational Behavior, Vol. 12, pp. 295-336.

Powell, W.W. (1998), Learning from collaboration: Knowledge and networks in the biotechnology and pharmaceutical industries, California Management Review, Vol. 40, No. 3, pp. 228-240.

Prashantham, S. and Birkinshaw, J. (2008), Dancing with Gorillas: How Small Companies Can Partner Effectively with MNCs, California Management Review, Vol. 51, No. 1, pp. 6-23.

Ring, P.S., Doz, Y. and Olk, P.M. (2005), Managing formation processes in R\&D consortia, California Management Review, Vol. 47, No. 4, pp. 137-155.

Shamsie, J., Martin, X. and Miller, D. (2009), In with the Old, in with the New: Capabilities, Strategies, and Performance Among the Hollywood Studios, Strategic Management Journal, Vol. 30, No. 13, pp. 14401452.

Strebel, P. (1996), Why do employees resist change?, Harvard Business Review, Vol. 74, No. 3, pp. 86-92. 
Suddath, C. (2012), Why There Are No Bosses at Valve, Bloomberg Businessweek, available at: http://www.businessweek.com/articles/2012-04-27/why-there-are-no-bosses-at-valve\#p1.

Uzzi, B. and Dunlap, S. (2005), How to Build Your Network, Harvard Business Review, Vol. 83, No. 12, pp. 53-60.

Valve. (2012), Handbook for New Employees, Valve Corporation, available at: http://newcdn.flamehaus.com/Valve_Handbook_LowRes.pdf.

Varoufakis, Y. (2012), Why Valve? Or, what do we need corporations for and how does Valve's management structure fit into today's corporate world?, Valve Economics, available at: http://blogs.valvesoftware.com/economics/why-valve-or-what-do-we-need-corporations-for-and-how-doesvalves-management-structure-fit-into-todays-corporate-world/.

Walls, B. (2012), Interview: Berkeley Garage Doors \& Repairs.

Whipple, J.M. and Frankel, R. (2000), Strategic alliance success factors, Journal of Supply Chain Management, Vol. 36, No. 3, pp. 21-28.

Wiesenfeld, B. and Cattani, G. (2010), Business Through Hollywood's Lens, Harvard Business Review, Vol. 88, No. 10, pp. 146-147.

Williamson, O.E. (1993), Calculativeness, Trust, and Economic Organization, Journal of Law \& Economics, Vol. 36, p. 453.

Williamson, P.J. and De Meyer, A. (2012), Ecosystem Advantage: How to Successfully Harness the Power of Partners, California Management Review, Vol. 55, No. 1, pp. 24-46.

Xin, K.R. and Pearce, J.L. (1996), Guanxi: Connections as substitutes for formal institutional support, Academy of Management Journal, Vol. 39, No. 6, pp. 1641-1658.

Yu, J., Gilbert, B.A. and Oviatt, B.M. (2011), Effects of Alliances, Time, and Network Cohesion on the Initiation of Foreign Sales by New Ventures, Strategic Management Journal, Vol. 32, No. 4, pp. 424-446. 